する方法を提案した. 此の方法は P.V.C.の分解過程に 拈ける眖塩酸の定量に簡便に適用することができ，従っ て熱安定性試験分解状況の研究等に用いて適当であると 考えられると共に，P.V.C. 中の全塩素の定量にも一貫 して用いることができる. 特秼な試菜器具実験設供を要 せず，同時に多数の試料を簡単正確に分析出来るので， 工場に打ける品質管理等にる用い得ると考光る.

終りに本研究に当り, 懇切な御指導を睗った京都大学 教授石橋雅義先生, 大日電線研究部長山田哲三氏，及び 本研究の一部につき熱心に協力された本学化学教室副手
松本延造君㴟く感謝する.

\section{女献}

1) 井本 : 化学, 8, 214 (1953).

2）吉田：“続・塩化ビニル樹脂の諸問题” 1, (1952).

3) A.S.T.M. D 793-44 T.

4) 水谷, 小林, 藤井 : 高分子化学, 8, 175 (1951).

5) 井本, 大津 : 工化，56， 615 (1953).

6) 山田, 山本: ゴム協会誌, 24, 40 (1951).

7) A. Tribot, R. Simson : C. A., 4091 (1948).

(日本女子大学*)

(昭和。29 年 5 月 8 日受理)

\title{
電気クロ マトグラフ法（第5 報）
}

錯イオン形成による無譏陽イオンの分離
牧 正 交

\section{Electrochromatography. V.}

MASAFUmi MaKi

(Japan Women's University)

Separation of Inorganic Cations by the Formation of Complex Ions.

1. Complex ions by using the Solution of Ethylendiamine- $\mathrm{NH}_{4}$ tartrate.

2. Complex ions by using the Solution of Triethanolamine- $\mathrm{NH}_{4}$ tartrate.

3. Complex ions by using the Solution of $\mathrm{Na}_{4} \mathrm{P}_{2} \mathrm{O}_{7}$.

In part IV separation of cations were reported by complex forming with $\mathrm{NH}_{4} \mathrm{OH}-\mathrm{NH}_{4}$ tartrate solution, some ions (seemed to form ammine complex ions) migrated to the anode side and others (seemed to form tartrate complex ions) to the cathode side, in this way mixed ions were separated in two ways from original point.

In the same way, results were reported where ethylendiamine and triethanolamine were used instead of $\mathrm{NH}_{4} \mathrm{OH}$ in this part.

Another method of separation of cations to be reported in the same time is the one which using the change of stability of complex ions prepared by $\mathrm{Na}_{4} \mathrm{P}_{2} \mathrm{O}_{7}$ solution with $\mathrm{pH}$ of the solution varies according to the ion. That is, in acidic side some ions forming complex ions with $\mathrm{Na}_{4} \mathrm{P}_{2} \mathrm{O}_{7}$ migrated to the anode side and others which unable to form complex ions to the cathode side, in this way mixed ions were separated in two ways as the first method. (Received, May 8, 1954)

\section{Ethylendiamine- $\mathrm{NH}_{4}$ tartrate 染液による錯} イオン形成による分䧳

2. Triethanolamine- $\mathrm{NH}_{4}$ tartrate 溶液による錯 イォン形成による分䧳

さきに電気クロマトグラフ法第 4 報” として, $\mathrm{NH}_{4}$ $\mathrm{OH}-\mathrm{NH}_{4}$ tartrate 溶液によって混合陽イオンの錯塩を 形成せしめると, 錯基が正に帯電する錯塩 (アムミン錯 塩と推定）と錯基が負に帯電する錯塩（酒石酸錯塩と推 定）とが生じ，混合陽イオンを湦紙の原点を中心として， 陽陰両原に分離し得, 極めて分離能か増大して, いわゆ る留気りロマトグラフ法の特色を発揮することができる ことをのべた．本報たおいては，これと同じ目的でNH OH の代りに Ethylendiamine および Triethanolamine を用いて陽イオンの分離をおこない，それぞれ異った分 淮状況を得たので報告する。
第 4 報の場合とほぼ同じである.両極液にはそれぞれ $0.11 \mathrm{M}$ Ethylendiamine—0.1 M NH $\mathrm{NH}_{4}$ tartarte あるい は $0.1 \mathrm{M}$ Triethanolamine-0.1 M NH 4 tartrate水 溶液 $150 \mathrm{cc}$ 宛を用いる.

試料としては, 各イオン 1 個当りについて, $0.05 \mathrm{M} の$ 試㸯陽イオン溶液 $0.25 \mathrm{cc}$ に上記の溶液 $1 \mathrm{cc}$ を加えて 錯塩を形成せしめ，これより $0.01 \mathrm{cc}$ をとって上記同溶 液を飽和せしめた溜紙の原点に附着せしめ, 200 Volt で 4 時間移動させる .

0. $11 \mathrm{M}$ Ethylendiamine-0. $1 \mathrm{M} \mathrm{NH}_{4}$ tartrate 溶液

\section{による分噰}

通常の定性分析の属ごとに第 1 〜第 5 㬂のイオンの分 離をおこなった。 そのうちの数例について，清紙上での 分離状況をしめすと第 1 ～ 3 図の如くである. 各単独イ オンの移動度を全イオンについてまとめて図示すると第 4 区の如くなる. 

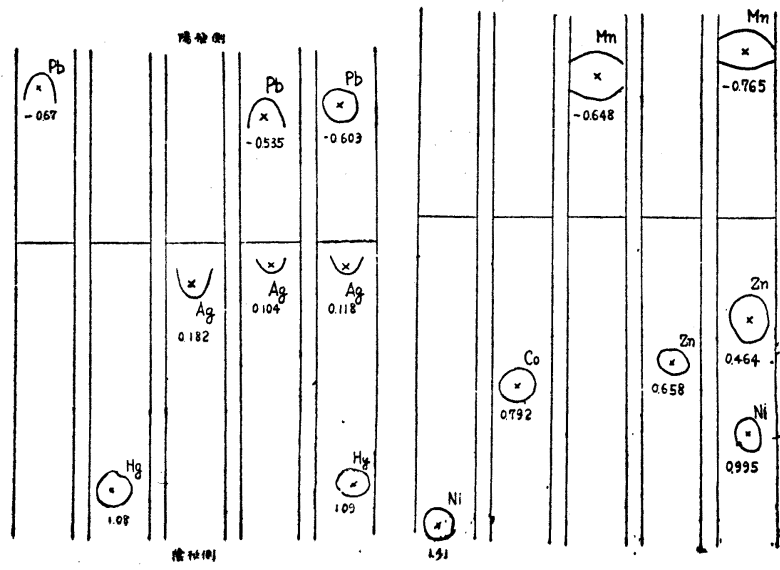

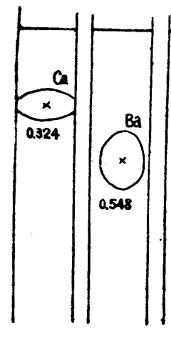

(8) (7) (6) (5)

第 3 因 No. 124

困の解說

第 1 図 No. 123

第

図 No. 117

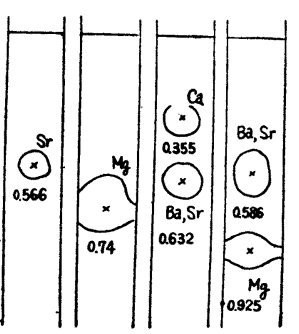

(2) (1)

第 1 困 No. 123 実験温度 $9.2 \sim 10.5^{\circ} \mathrm{C}$ 電流 $6.0 \sim 9.0 \mathrm{~mA}$ 顕色 $\left(\mathrm{NH}_{4}\right)_{2} \mathrm{~S}$

第 2 図 No. 117 実験温度 $16.2 \sim 16.5^{\circ} \mathrm{C}$ 電流 $4.3 \sim 7.0 \mathrm{~mA}$ 顕色 Ni Dimethylglyoxime $\mathrm{NH}_{3} ; \mathrm{Co}\left(\mathrm{NH}_{4}\right)_{2} \mathrm{~S}$ Mn Diphenylcarbazide, $\mathrm{NH}_{3} ; \mathrm{Zn}$ Dithizon

第 3 図 No. 124 実験温度 $7.0 \sim 11.8^{\circ} \mathrm{C}$, 電流 $6.0 \sim 9.8 \mathrm{~mA}$ 顕色 $\mathrm{Ca}, \mathrm{Mg}$ Alizarin in Alcohol, $\mathrm{NH}_{3}$

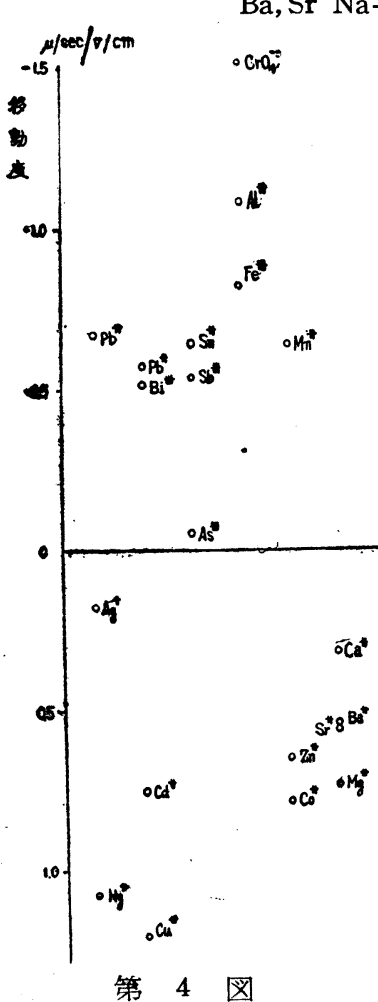

0.11 M Ethylendiamine-0.1 M $\mathrm{NH}_{4}$ tartrate $\mathrm{Kよb}$ 各単独人 オンの移動度（各属の平均実験 温度 $13 \pm 3.5^{\circ} \mathrm{C}$ )

第 4 報1 では $\mathrm{NH}_{4} \mathrm{OH}$ に対して $\mathrm{NH}_{4}$ tartrate のモ ル比を变えた場合に备イオンの分離状況を变化し得るこ

\footnotetext{
* 第 4 報の場合と同じ意味で $\mathrm{Hg}_{2}{ }^{++}$の代りk镇用
}

とをのべたが, Ethylendiamine- $\mathrm{NH}_{4}$ tartrate の場合 においても相にその 1 方の成分を变化させて，イオン の移動度に欧ぼす影響を調べた。すなわち Ethylendiamine を0.22 M で一定とし， $\mathrm{NH}_{4}$-tartrate を变化させ た場合と, $\mathrm{NH}_{4}$-tartrate を $0.1 \mathrm{M}$ で一定にして

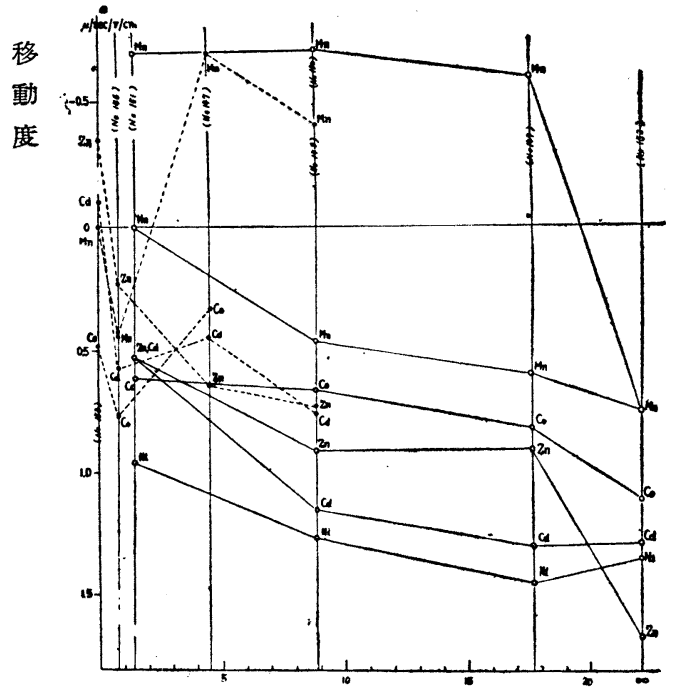

Ethylendiamine $/ \mathrm{NH}_{4}$ tärtrateのモル比 乘、 5 因

Ethylendiamin/ $\mathrm{NH}_{4}$ tartrare の Mol 比を变えた ときのイオンの移動度の変化 $(200 \mathrm{~V}, 4 \mathrm{hr}$; 平均実 験温度 $15 \pm 1.5^{\circ} \mathrm{C}$ )

O印 Ethylendiamine $0.22 \mathrm{M} \mathrm{K}$ 一定

印 $\mathrm{NH}_{4}$ tartrate $0.1 \mathrm{M}$ K一定

Ethylendiamine 量を变化させた場合について, $\mathrm{Ni}^{++}$, $\mathrm{Co}^{++}, \mathrm{Mn}^{++}, \mathrm{Zn}_{\mathrm{n}}^{++}, \mathrm{Cd}^{++}$の移動度变化を詞べた. Ethy- 


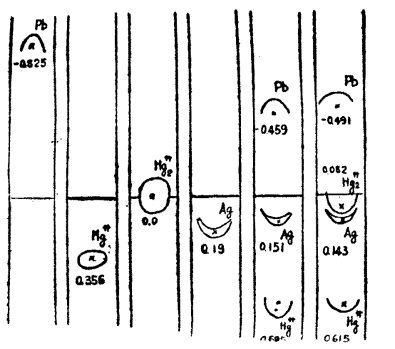

(3)

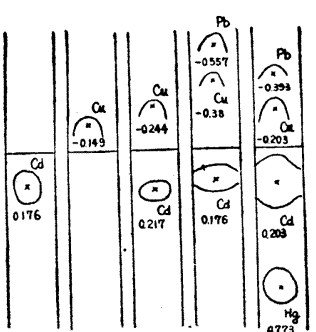

(4) (5) (6) (7) 8) 第 7 図 No. 129

第 6 図 No.133

No133 実験温度 $16.7 \sim 15.9^{\circ} \mathrm{C}$, 電流 $8.8 \sim 12.3 \mathrm{~mA}$ No129 実験温度 $11.6 \sim 17.5^{\circ} \mathrm{C}$ 電流 $7.4 \sim 12.5 \mathrm{~mA}$ No132 実験温度 $17.2 \sim 16.5^{\circ} \mathrm{C}$ 電流 $8.8 \sim 12.3 \mathrm{~mA}$ No130 実験温度 $11.5 \sim 16.5^{\circ} \mathrm{C}$ 電流 $6.0 \sim 11,0 \mathrm{~mA}$ lendiamine と $\mathrm{NH}_{4}$ tartrate のモル比の变化に対す るイオンの移動度の变化は第 5 図の如くである. (図中 モル比 0 の点は $0.1 \mathrm{M} \mathrm{NH}_{4}$ tartrate のみ, $の$ 点は Ethylendiamine のみの場合をしめす) 概してEthylendiamine 量を変化させた方が，イオン相互の移動度の 変化が大きいよ5に見受けられる.すなわちイオンの分 離状況を变化させるには Ethylendiamine の方を变え た方が効果的と考える.

0. 1 M Triethanolamine-0.1M $\mathrm{NH}_{4}$ tartrate 溶液による分離

Ethylendiamine- $\mathrm{NH}_{4}$ tartrate

の場合と同じように

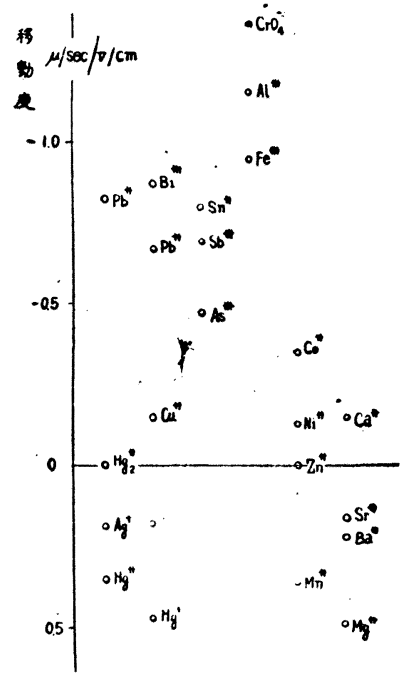

第 10 図

0.1 M-Triethanolamine-0. 1 M $\mathrm{NH}_{4}$ tartarate とよる各単 独イオンの移動度 (各属の平均 実験温度 $15.5 \pm 1.5^{\circ} \mathrm{C}$ )

ている.

括

Ethylendiamine- $\mathrm{NH}_{4}$ tartrate, TriethanolamineNH。 tartrate による陽イオンの分離を持こない，各
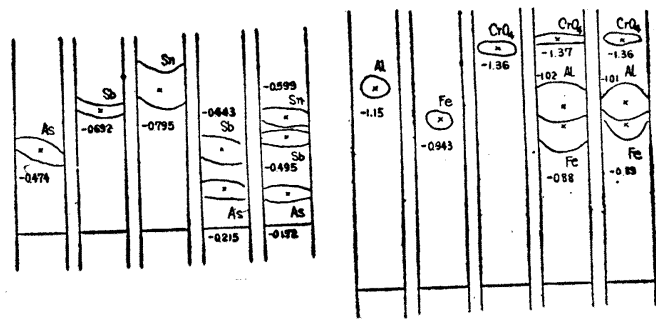

(2) (3) (1) (7) (5)

(3) (2) (1) (6) (7)

図 8 図 No. 132

第 9 図 No. 130

顕色 $\left(\mathrm{NH}_{4}\right)_{2} \mathrm{~S}$

顕色 (4) (7) $\left(\mathrm{NH}_{4}\right)_{2} \mathrm{~S}$; (8) Diphenylcarbazide, $\mathrm{NH}_{3}$ 影色 $\mathrm{As}, \mathrm{Sb}\left(\mathrm{NH}_{4}\right)_{2} \mathrm{~S} \mathrm{Sn}$ AlizarinS, $\mathrm{NH}_{3}$

顕色 $\mathrm{Al}, \mathrm{Fe}$ AlizarinS, $\mathrm{NH}_{3} ; \mathrm{CrO}_{4}$ そのままで着色

属のイオンの分離には, 第 4 報 ${ }^{\prime}$ の場合に比較して, 第 5 属の分離には, Ethylendiamine- $\mathrm{NH}_{4}$ tartrate $に$ よる方法が $\mathrm{As}^{+++}, \mathrm{Sb}^{+++}, \mathrm{Sn}^{++}$及び第3 属の分離に は Triethanolamine-NH\& tartrate による方法の方が すぐれている. しかしながら第4 属のイオンの分離には 第 4 報1 の $\mathrm{NH}_{4} \mathrm{OH}-\mathrm{NH}_{4}$ tartrate による方法の方が よい.

なお本報の 2 つの方法は第 4 報”の方法とはとれぞれ 異る分離状況を得ているから，任意の混合イオンの分離 に対してこれらの方法の内から最も適当な方法を見いた すことができよう.

Ethylendiamine と $\mathrm{NH}_{4}$ tartrate の比即り 2 成分 の比を变えることによって分離状況を变化し得ることは 第 4 報”の場合と同様である.

\section{3. 燐酸溶液による錯イオン形成による分離}

\section{$\mathrm{Na}_{4} \mathrm{P}_{2} \mathrm{O}_{7}$ による分離}

第4 報1 及び本報において前述 1,2 の方法は，いず れも混合陽イオンについて，あるるのは錯基が正に帯琨 するアムミン錯塩を，他のものは錯基が負に帯電する 酒石酸錯塩を形成せしぬて, 混合イオンを滤紙の原点を 中心として陽，陰両極に分離したが，ここにのべる方法 はつぎのような考方方から出発した新しい方法である. すなわち混合陽イオンについて，その 1 部のものを錯基 が負に带電する錯塩を形成せしめ，他は陽イオンのまま 残して，イオンを陽，陰両極に大きく分離せんとするも のである.

この目的のためには，中性乃至酸性で錯塩をつくる試 薬が適当と考えた. なおとの錯塩はあまり安定すぎると 顕色が困難になるから, 顕色可能なる程度の適当なる安 定度をもった錯塩でなければならない.この目的のため に 1 例として $\mathrm{Na}_{4} \mathrm{P}_{2} \mathrm{O}_{7}$ を考えた. $\mathrm{Na}_{4} \mathrm{P}_{2} \mathrm{O}_{7}$ 水溶液単独 で用いるときはアルカリ土類に属するイオン迄錯塩をつ くるが，その錯イオンの移動距離がイオンによって相互 に余り異ならぬため分離目的には適さない，しかしなが らこれに酸を加えて $\mathrm{pH}$ を下げてゆくと, 各イオンの錯 塩の安定性が，イオンが異ると变化するであら5と考え た.これを調べるために, $\mathrm{Ni}^{++}, \mathrm{Co}^{++}, \mathrm{Zn}^{++}, \mathrm{Cd}^{++}$, 
$\mathrm{Cu}^{++}$の 5 イオンを試験用試料として, $\mathrm{Na}_{4} \mathrm{P}_{2} \mathrm{O}_{7}$ に対し て塩酸を種ふの割合に添加してつくった $\mathrm{pH}$ の異る種々 の溶液をそれぞれ飽和させた濾紙に附着せしめて溶液の $\mathrm{pH}$ 変化によるイオンの移動度の变化を測定した.

\section{実験方法}

第 4 報” の場合とほぼ同様であるが，各イオン 1 個当 りにつき， $0.05 \mathrm{M}$ の各試料イオン溶液 $0.5 \mathrm{cc}$ に0. 0375 $\mathrm{M} \mathrm{Na} \mathrm{P}_{2} \mathrm{O}_{7} 400 \mathrm{cc}$ に $2 \mathrm{~N} \mathrm{HCl}$ を種々の割合に添加して $\mathrm{pH}$ を $1.6_{5} \sim 10.7$ の間で 5 種類に变化させた各種の $\mathrm{pH}$ の溶液をそれぞれ $1 \mathrm{cc}$ 宛加え, その中から，0.02 ccを とって，同溶液で飽和させた濾紙の中央部にある原点に 附着せしめ 200 Volt で 4 時間移動させた.なお極液に は同溶液 $150 \mathrm{cc}$ 宛用い，電極として白金線を用いた。

\section{実験結果むよび考察}

極液の $\mathrm{pH}$ 変化によるイオンの移動状況の变化は第11 図の如くで, $\mathrm{Na}_{4} \mathrm{P}_{2} \mathrm{O}_{7}$ 溶液のみ $(\mathrm{pH} 10.7)$ の場 合には 各イオンはほとんど同じ移動度をしめし分離し難いが， pH が下るにつれて予想の如く各イオンは次第に分離さ れてくることがわかる. 図におけるイオンでは $\mathrm{pH}$ 2.5〜 pH 5 の間でもっと分離度が大きくなってい る.

この例にみる如く， $\mathrm{pH}$ を変化させることによって， そのイオンの分離にもつとも適当な点を求め得ると考元 る.

この方法を用いて普通の定性分析の属について，イオ ンの分離をおこなった例を第12図, $\mathrm{As}^{+++}, \mathrm{Sb}^{+++}, \mathrm{Sn}^{++}$ の分離 (pH2.4), 第 13 図 $\mathrm{Al}^{+++}, \mathrm{Fe}^{+++}, \mathrm{CrO}_{4}^{--}$の分離 (pH 2.4), 第 14 図 $\mathrm{Ca}^{++}, \mathrm{Ba}^{++}, \mathrm{Sr}^{++}, \mathrm{Mg}^{++}$の分離 $(\mathrm{pH}$ 3.2) にしめす. かくの如く普通のクロマトグラフでは 分離困難なる $\mathrm{Sb}^{+++}, \mathrm{Sn}^{++} ; \mathrm{Al}^{+++}, \mathrm{Fe}^{+++}, \mathrm{CrO}_{4}^{--}$ が容易にこの方法で分離された。

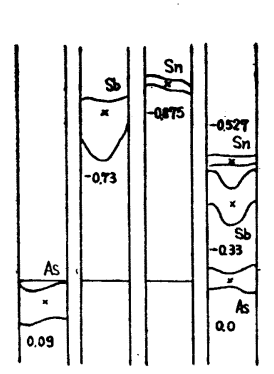

(6) (7) (8) (9)

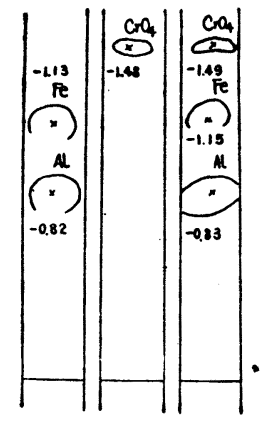

(4) (3) (5)

第12図 No. 160

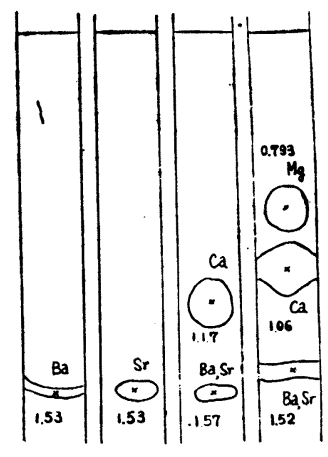

(3) (2) (7) (8)

第14図 No. 159

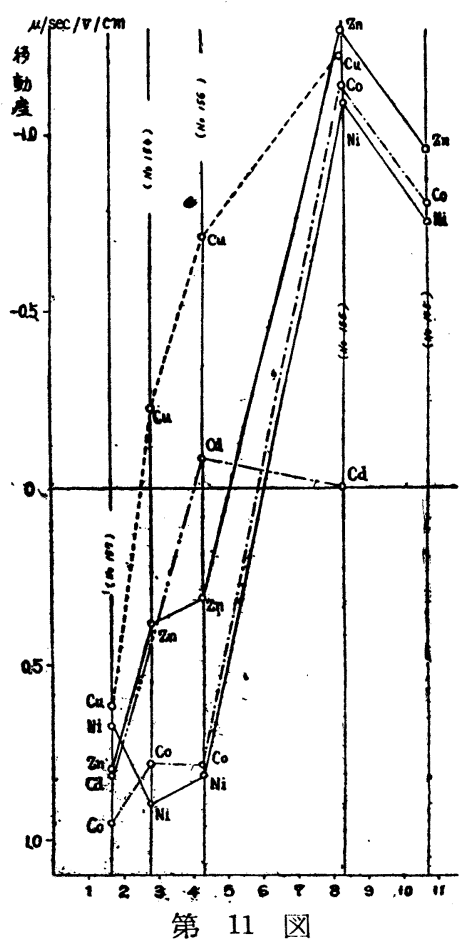

$\mathrm{Na}_{4} \mathrm{P}_{2} \mathrm{O}_{7}$ K対する $\mathrm{HCl}$ 添加量によ $9 \mathrm{pH}$ 变化さ せたとをのイオンの移動度の变化平均実験温度

No $15726.5^{\circ} \mathrm{C}$; No $15,15515619 \pm 2^{\circ} \mathrm{C}$; No4145 $24.9^{\circ} \mathrm{C}$

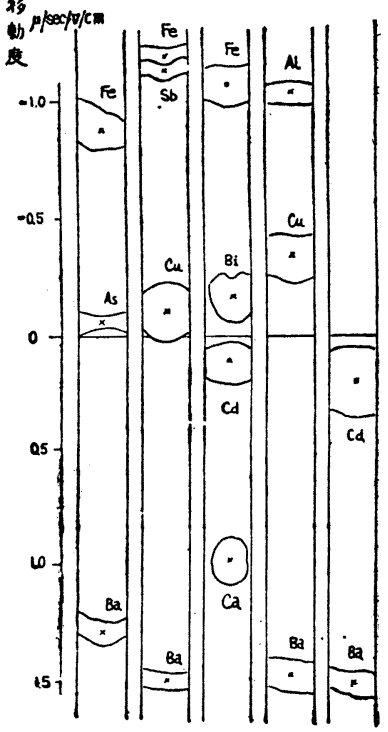

(1) (4) (5) (7) (8)

第15図 No. 162 
また定性分析の間属にまたがる任意の混合イオンの分離 例を第 15 図 (pH 2.5) にしめ寸．以上イオンの分離例 でみられるよ5に, 混合してもイオンの移動度は単独の 場合と余り異ならぬから，一般に単独イオンの移動度の 異るものは, その $\mathrm{pH}$ において分離し得ると考えられる. 総 括

$\mathrm{Na}_{4} \mathrm{P}_{2} \mathrm{O}_{7}$ 水溶液に塩酸を添加した種々の $\mathrm{pH}$ の溶液を 極液とし, 同液で飽和せられた滤紙上に, 試験用の試料と して $\mathrm{Ni}^{++}, \mathrm{Co}^{++}, \mathrm{Zn}^{++}, \mathrm{Cu}^{++}, \mathrm{Cd}^{++}$を附着せしめて極液 の $\mathrm{pH}$ 变化による各イオンの移動度変化を調べた. $\mathrm{Na}_{4} \mathrm{P}_{2}$ $\mathrm{O}_{7}$ 溶液単独では, 各イオン相互の移動度は变らないか; 塩酸を加えて $\mathrm{pH}$ をさげるに従ってイオン毎に錯塩の安 定性が変化して，あるイオンほ錯イオンを形成して陽極 側に移動し，他は錯イオンを形成しなくなって（厳密に は錯イオンの安定度が小となる）陰極側に移動し, イオ ン群を陽陰両極に分離し得て，分離度が極めて大きくな る. 酸性度が更に大きくなると, すべてのイオンは陰極 側に移動する.
したがって一般にある湿合イオンを分離するには，そ の分離にもつとも適当な $\mathrm{pH}$ を求めればよい. 1 例とし て, $\mathrm{pH} 2.4$ において $\mathrm{As}^{+++}, \mathrm{Sb}^{+++}, \mathrm{Sn}^{++} ; \mathrm{Al}^{+++}$, $\mathrm{Fe}^{+++}, \mathrm{CrO}_{4}^{--}$及び $\mathrm{pH} 3.2$ において $\mathrm{Ca}^{++}, \mathrm{Ba}^{++}\left(\mathrm{r}^{++}\right)$, $\mathrm{Mg}^{++}$が極めて良く分離された。

本法は $\mathrm{Na}_{4} \mathrm{P}_{2} \mathrm{O}_{7}$ はアルカリ土類に属するイオンまで 錯塩形成能力があるから，アルカリ土類のイオンを含め た広範讲のイオンの移動状況を变化せしめ得る興味ある 分離法と考える.

第 4 報1 及び本報に錯塩形成による多種多様の分㒕法 をあげたが, $\mathrm{Ba}^{++}, \mathrm{Sr}^{++}$の相互の分離を除いては主なる 陽イオン 20 余種 $\left(\mathrm{CrO}_{4}^{--}\right.$は例外) 相互の分離か可能 になった。（昭29.4.3 日本化学会年会講演）

本研究に御指導, 御助言を載いた東京工業大学教授植 村琭先生, 同岩崎岩次先生, 金沢大学助教授柴田村治氏 に厚く感謝致します。

$$
\text { 女献 }
$$

1) 牧: 分析化学, 3, 393 (1954).

(東京薬科大学女子部*) (昭和 29 年 5 月 25 日受理)

\title{
臭素酸塩のマンガン塩による確認法について
}

\author{
深間内久雄・小幡幸子 \\ Detection of Bromate Ion by Use of Manganese Salts
}

\author{
Hisao Fukamauchi and Sachiko Obata \\ (Women's Division, Tokyo College of Pharmacy)
}

\begin{abstract}
It is generally described that the reaction of manganese salts with bromic acid is a confirming test for bromate ion in the presence of chlorate. This is based on the repotts of Vitali" and Monni$\mathrm{er}^{2}$, according to which manganous salts are oxidized to manganic salts or manganese dioxide by bromic acid, but not by chloric acid. In order to examine the above statement, experiments have been carried out and found that manganese salts are also oxidized by chloric acid; as a result, for identification of bromate ion by the reaction of manganese salts, it is necessary to detect the bromine produced by this reaction. The limit of detection of bromate ion by this method is $13 \gamma / 0.25$ cc, and the limit of concentration is $1 / 20000$; the sensitivity is better than that given by Feigi ${ }^{3}$.
\end{abstract}

(Received May 25, 1954)

\section{I 緒}

臭素酸とマンガン塩の反応は, 塩素酸イオンの共存に おける臭素酸イオンの検出反応として一般に記載されて

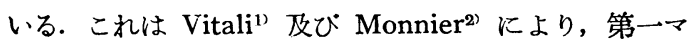
ンガンは臭素酸により酸化されて第二マンガン乃至二酸 化マンガンとなるが，塩素酸によってはこの反応が行わ れないと報告されていることに基く、筆者等はこの記載 に疑問を持ち次の実験を行い, 第一マンガンが㙁素酸に よっても酸化されることを確め, 臭素酸塩をマンガン塩 の反応によって塩素酸塩と判別して確認するには，反応 によって生ずる臭素の検出を必要とすることを明かにし t.

\section{II マンガン塩による具素酸の確認限度}

Feigl ${ }^{3)}$ によれば,硫酸々性硫酸マンガン溶液に臭素酸 埴を加えて加熱した後，ベンジジン及び酷酸ソーダを加
える方法により, 確認限度: $\mathrm{KBrO}_{3} 40 \gamma$, 限界濃度： $\mathrm{KBrO}_{3} 1 / 2500$ である. ミクロ試験管を用い，精製した 臭素酸ナトリウム溶液についてこの確認法を再検討する と次の結果を得る．な打硝酸に性硝酸マンガン溶液を試 薬とする方法についてす検べた.

$\mathrm{NaBrO}_{3} 5$ 滴 $+10 \% \mathrm{H}_{2} \mathrm{SO}_{4} 1$ 滴 $+10 \% \mathrm{MnSO}_{4} 1$ 滴 $\rightarrow$ 加等 $\rightarrow$ 黒褐色, +ベンジジン酢酸溶液＋醀酸 ナトリウム固体小粒 $\rightarrow$ 青色

確認限度 : $\mathrm{BrO}_{3}-13 \gamma / 0.25 \mathrm{cc}$

限界濃度 : $\mathrm{BrO}_{3}-1 / 20000$

$\mathrm{NaBrO}_{3} 5$ 滴 $+25 \% \mathrm{HNO}_{3} 1$ 滴 $+10 \% \mathrm{Mn}\left(\mathrm{NO}_{3}\right)_{2} 1$ 滴 $\rightarrow$ 加熱 $\rightarrow$ 黒褐色, +ベンジジン酢酸溶液＋酢酸 ナトリウム固体小粒 $\rightarrow$ 青色 確認限度: $\mathrm{BrO}_{3}{ }^{-} 13 \gamma / 0.25 \mathrm{cc}$

* 東京都台東区上野桜木町 